\title{
Boom, or bust?
}

\author{
Hundreds of millions of dollars are pouring into US biodefence research. \\ You might expect scientists working on infectious diseases to be \\ unequivocally delighted. But things aren't that simple, says Erika Check.
}

$\mathrm{T}$ hree years ago, Karl Hostetler founded a company called Chimerix, based on an eminently practical, if unglamorous, idea. Hostetler, who works at the University of California, San Diego, had invented a way to repackage the antiviral drug cidofovir so that it could be taken as a pill rather than intravenously. Faced with 'sexier' investment opportunities, however, venture capitalists weren't much interested,

But in March 2002, Chimerix's fortunes changed dramatically. At a meeting in Prague, Hostetler and his colleagues revealed and the company's prospects looked bleak.

that cidofovir blocks smallpox infections in human cells and lab mice. The US government was searching desperately for smallpox treatments that could counter a potential bioterrorist attack, and giving patients cidofovir pills would be much easier than putting thousands of people on intravenous drips. So in September this year, the National Institute of Allergy and Infectious Diseases (NIAID), based in Bethesda, Maryland, gave Chimerix a five-year, \$36-million-dollar grant to make and test cidofovir pills. "I doubt very much that we would have been able to obtain venture-capital funding to pursue this smallpox

\section{A cause célèbre}

The sight of a highly respected 62-year-old professor being hauled into a courtroom day after day would be unsettling enough for researchers under any circumstances. But the trial of plague researcher Thomas Butler has profoundly disturbed the US scientific community, which sees him as the victim of a misguided and vindictive government prosecution. Although Butler was cleared on 1 December of the most serious charges laid against him, prominent microbiologists argue that the case will ultimately undermine the US biodefence effort by scaring researchers away from the field.

Butler, who has spent his life studying the bacteria that causes plague, told federal officials in January that some plague samples had gone missing from his lab at Texas Tech University in Lubbock. Investigators who quizzed Butler concluded that he had destroyed the samples and then lied about it, and charged him with making false statements to the FBI.

Butler was cleared of lying to federal investigators, but was found guilty of crimes including theft, defrauding his university and

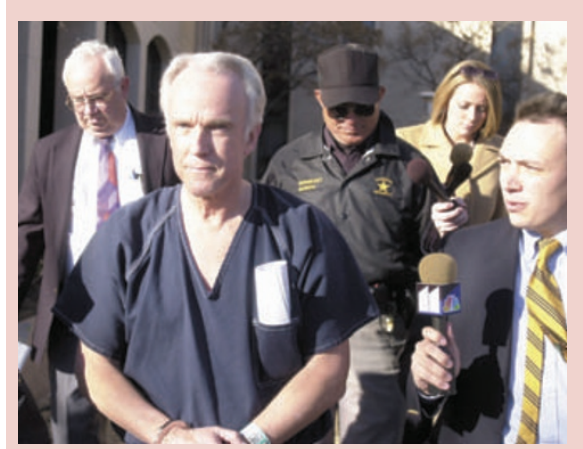

On trial: Thomas Butler outside the courthouse. illegally transporting plague samples overseas. Texas Tech has moved to dismiss him, and he has spent his life's savings on his defence. As Nature went to press, he had yet to be sentenced.

Many researchers argue that the rules regarding transport and possession of 'Category $A$ ' pathogens - such as the plague bacterium - are so complicated that even experienced scientists such as Butler are confused. They are appalled that Butler was jailed for six days without bail and has endured months of house arrest. In a letter to the Justice Department sent on 15 August, the presidents of the US National Academy of Sciences and the Institute of Medicine wrote that Butler's trial could undermine biodefence research. Four Nobel prizewinning scientists repeated that warning on 3 November, the day on which Butler's trial began. "This respected colleague has been subjected to unfair and disproportionate treatment and the case is having a negative impact on the future of research in this crucial national-security-related field," the laureates said.

Butler's case did not deter researchers from applying for the grants made available for biodefence this year. Much of this money went to researchers who are new to the field. But those who have worked with plague bacteria before have been more cautious. Stanley Falkow, a microbiologist at Stanford University in California, says that he has destroyed his plague samples. On 18 September he wrote to US Attorney General John Ashcroft, arguing that the government's excessive zeal for biosecurity has trampled over Butler's rights, and asking: "How could I possibly permit my students and myself to be subject to the same nightmare if we also made an inadvertent mistake?" application,” says Chimerix vice-president Kevin Anderson. "Given the investment climate of the past couple of years, it would have been virtually impossible."

Chimerix's windfall illustrates one side of the current boom in US biodefence spending. Since the still-unsolved mailed anthrax attacks of October 2001, NIAID has handed out some $\$ 1.8$ billion for biodefence research. The money has allowed scientists such as Hostetler and his Chimerix colleagues to pursue work that should make the world a safer place.

But others see signs of trouble in the biodefence bonanza. Some researchers fear that it will distort priorities in infectiousdisease research, sucking money away from work to understand and counter natural disease outbreaks that ultimately pose a greater threat to public health. Experts in weapons proliferation, meanwhile, are concerned that the expansion of labs working on potential bioweapons agents will increase the risk of these pathogens getting into terrorists' hands. And many microbiologists are confused and worried by the regulatory framework put in place to reduce this risk - they now fear being dragged through the courts by overzealous federal investigators over an innocent administrative slip-up. Indeed, these worries have been stoked to fever pitch by the prosecution, for alleged breaches of biosafety regulations, of plague researcher Thomas Butler of Texas Tech University in Lubbock (see 'A cause célèbre', left).

\section{Building blocks}

So far, the main way in which the influx of biodefence funding has changed the US scientific landscape is by supporting the creation of a network of new labs and centres. A year ago, there were just three maximumsecurity biosafety-level-4 (BSL-4) labs in the United States, where scientists could work on deadly and infectious airborne pathogens such as the smallpox virus. But thanks to NIAID funding, this capacity will be more than doubled. The agency is building two new BSL-4 labs - one in Fort Detrick, Maryland, on the campus of the US Army Medical Research Institute of Infectious Diseases, which already has its own BSL-4 lab, and the other at NIAID's Rocky Mountain Laboratories in Hamilton, Montana. In September, NIAID gave \$120 million each to Boston University and the 
University's Weill Medical College in New York, claims that NIAID has since withheld the 'bridging funds' that it normally awards to scientists whose research proposals do not quite pass muster on first review but are likely to be approved in the next round if they revise their grant applications in response to referees' comments. NIAID officials say that the budget for bridging funds is the same this year as last. But Moore's complaints are symptomatic of the distrust that has been sown by the diversion of funds to the anthrax-vaccine programme.

Given that his own background is in AIDS research, Fauci is sensitive to the concerns of those working on HIV. But he argues that the anthrax-vaccine situation is atypical. The US Congress is still trying to pass the 'BioShield' bill to fund the development and purchase of countermeasures against biological attacks. Once it is passed, Fauci says, there will be no need to raid NIAID's funds in this way. "It was an outlier," he says.

Fauci also argues that the increase in biodefence research, in particular that on ways to boost human immune responses to bioterror agents, will spill over into other areas of infectious-disease medicine. "The commitment we have made to this area is extraordinary," he says. "It cannot help but boost the entire field." Fauci points in particular to an allocation of $\$ 85$ million over five years to establish five 'Cooperative Centers for Translational Research on Human Immunology and Biodefense’.

\section{Act natural}

Some of the work funded under this programme is directed at combating natural disease outbreaks rather than bioterrorist threats. For instance, Stanford microbiologists Ann Arvin and Harry Greenberg have received \$15 million to study influenza vaccines. They will compare two different types of vaccine: the traditional jab containing killed flu viruses, and an inhaled vaccine based on live, weakened viruses, that was approved by the US Food and Drug Administration this year. In studying immune responses to both types of vaccine,
Arvin and Greenberg will investigate such fundamental questions as how cells of the immune system communicate with one another.

Another new project, based at Emory University School of Medicine in Atlanta, Georgia, will compare the body's immune responses to anthrax and yellow fever vaccines. Rafi Ahmed, who heads the Emory Vaccine Center, says that the work will include investigations of how the vaccines induce long-term immunity. So far, this has been studied extensively only in lab animals. "I still think of this as basic research, but now it's basic research in humans instead of mice," Ahmed says. "It's a great opportunity to do some fundamental work on human immunity that is very relevant to the biodefence effort."

Behind such scientific questions, however, lurk a host of other issues - not least the risk of proliferation from the increased number of labs working on potential bioweapons agents. "I think our security will decrease, because access to dangerous pathogens and expertise in working with them is going to
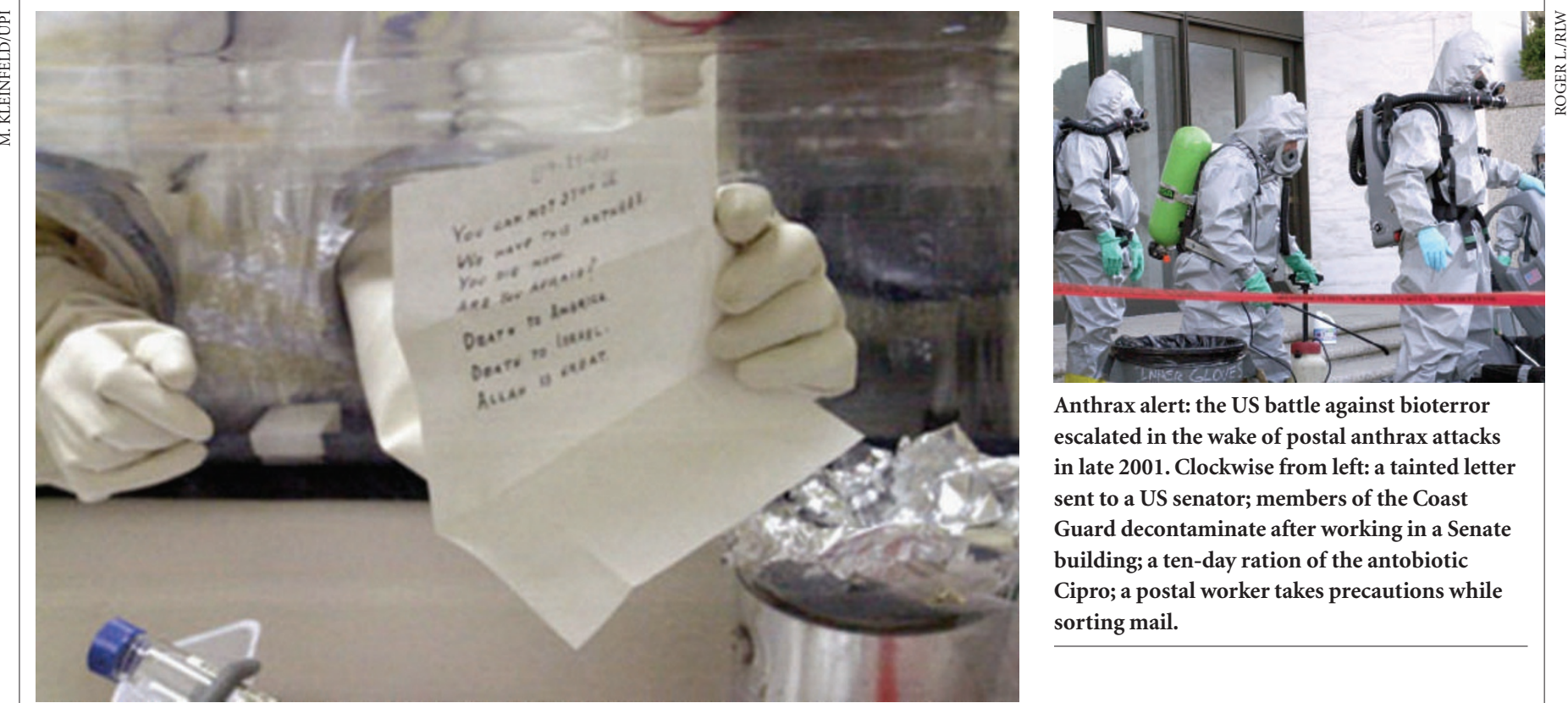

Anthrax alert: the US battle against bioterror escalated in the wake of postal anthrax attacks in late 2001. Clockwise from left: a tainted letter sent to a US senator; members of the Coast Guard decontaminate after working in a Senate building; a ten-day ration of the antobiotic Cipro; a postal worker takes precautions while sorting mail.
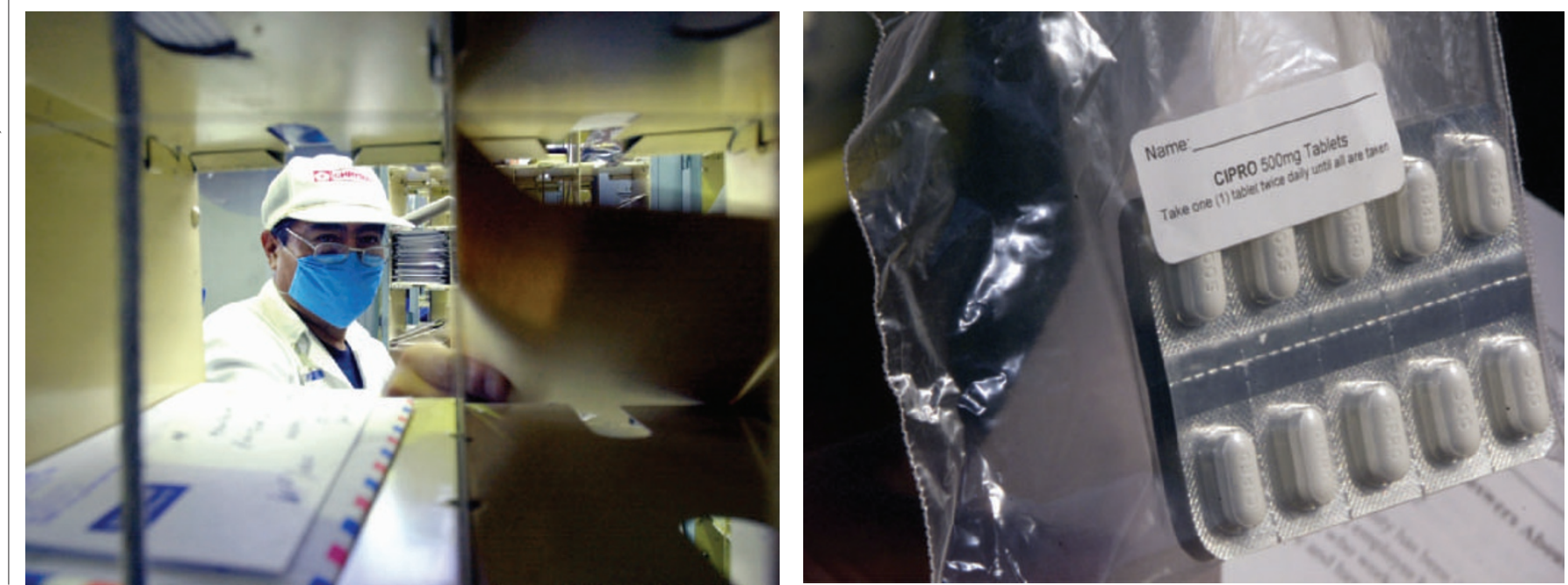
increase vastly, and along with that will go a vast increase in the possibility of accidental escape, misuse, theft and bioterrorism," argues Barbara Rosenberg, an expert on bioweapons issues with the Federation of American Scientists in Washington DC. Her concern is underscored by evidence gathered by the FBI, in its inquiry into the 2001 anthrax attacks, suggesting that the perpetrator may have had links to the US military's biodefence establishment.

Given the risk of proliferation, the federal government has called on researchers to demonstrate that they will behave responsibly. In response, leading scientific journals have drafted policies to deal with biological research that has the potential for misuse ${ }^{1}$. But many experts argue that the issue needs to be addressed further upstream, at the point at which research proposals are considered for funding. In October, an expert panel of the US National Research Council, chaired by Gerald Fink, a geneticist at the Massachusetts Institute of Technology, recommended that the federal Department of Health and Human Services set up a 'National Science Advisory Board for Biodefense'. This body would review all research funded by any US source, including private industry, that falls in one of seven "categories of concern", including work that would make a virus more deadly. As Nature went to press, researchers were still awaiting a response to these recommendations from the federal government.

\section{Fear factor}

In parallel, federal officials have been tightening the regulations that govern research on potential bioweapons agents, and stepping up their scrutiny of researchers who are working on such pathogens. Some researchers argue that this is creating a climate of fear that will drive talented individuals away from the field, however attractive the funding opportunities. "I'm afraid of these people," says one researcher working with category A agents, who asked to remain anonymous. "The FBI hasn't been able to come up with the real perpetrators of the anthrax attacks, and they're under a lot of pressure." As a result, he claims, federal officials are determined to make an example of anyone who is caught in breach of regulations that many researchers find confusing.

The Butler case represents an extreme example of the pressures that are being brought to bear on researchers working on potential bioweapons agents. But other scientists have been troubled by the public scrutiny that work on biodefence can attract (see 'Under the microscope', above right).

Nevertheless, a quick scan of US researchers now working in biodefence reveals that top scientists have not yet been scared away en masse. Indeed, their ranks include

\section{Under the microscope}

In May 2002, Ariella Rosengard of the University of Pennsylvania in Philadelphia published the results of a painstaking study that she hoped would help to defend against a future bioterrorist attack using smallpox. But she now wonders whether the publicity garnered by her project has actually undermined her research.

Rosengard was working with vaccinia, a relatively harmless cousin of the deadly smallpox virus. In her study, she mutated one of vaccinia's genes so that it produced a protein found in the smallpox virus, and then investigated how this protein inhibits enzymes that function in an arm of the immune system known as complement ${ }^{2}$.

Clearly, anyone who repeated Rosengard's methods could make vaccinia into a much more dangerous virus. But she argued that the results opened avenues for developing drugs to counter a potential smallpox attack — and a commentary published alongside her paper agreed that the work was "far more likely to stimulate advances in vaccinology or viral therapy than it is to threaten biosecurity"3. In October, an expert panel of the US National Research Council, established to consider the proliferation risks posed by biological research, concluded that Rosengard's work will stimulate research into new treatments and vaccines.

Rosengard's paper attracted attention from the media, the scientific community and the US government. She was invited to meetings with Central Intelligence Agency officials and White House scientific advisers. She was also asked to speak at a meeting of scientists and government officials at the National Academies of Science about her decision to publish her work.

Rosengard didn't question her decision to publish until this spring, when she submitted a grant application to the National Institute of Allergy and Infectious Diseases (NIAID) in

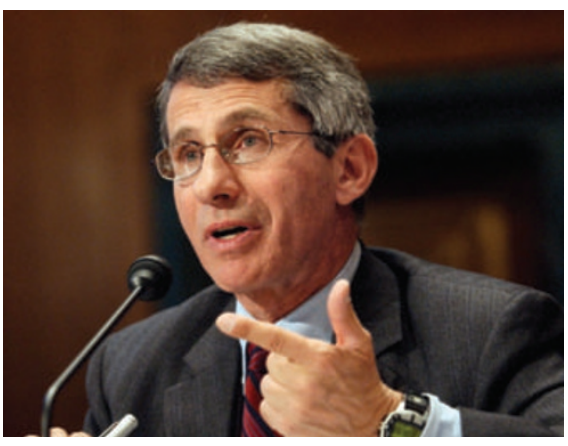

NIAID chief Anthony Fauci says biodefence funds will boost infectious-disease research in general.

some of the most highly regarded experts on infectious diseases. But even those who remain relatively relaxed about their regulatory environment are uneasy about the federal government's long-term commitment to the field. As a result, they say that they would think twice before recommending that young researchers commit themselves to specializing in biodefence projects. "I'm not sure there's enough

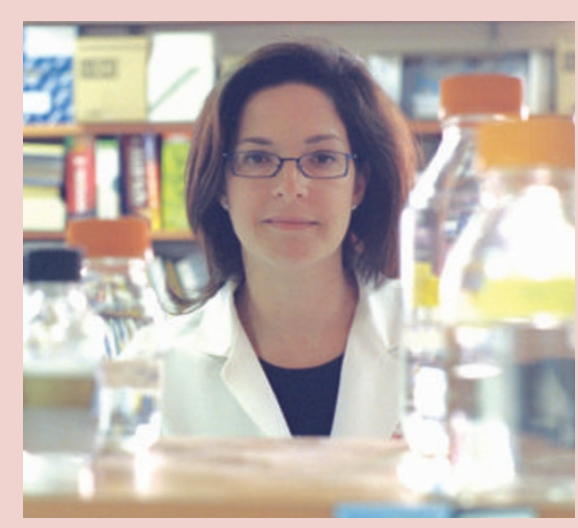

Ariella Rosengard's research sparked fears that her methods could be adapted by bioterrorists.

Bethesda, Maryland. Given the direct relevance of her work to smallpox, Rosengard felt certain to get a slice of the biodefence funding pie. But it didn't even make the first cut. "I was surprised and perplexed - everyone was," Rosengard says. "Few others had any data to go on."

Rosengard's lack of funding may force her to shut down her lab. She is on leave from her post and has moved to Cambridge, UK, with her cardiologist husband. She is undecided over whether to apply for funding next year.

NIAID director Anthony Fauci says that the agency does not discuss individual grant applications. "What drives our awarding of grants and contracts is scientific merit - that always has been and always will be," he says.

But Rosengard cannot help but wonder whether the controversy over her paper influenced the decision not to support her work. "If you don't get funded, you have to ask whether people didn't understand what you were proposing, or whether there was some other reason," she says.

information out there yet for people to make informed choices about swtiching careers," says Clare Fraser, president of The Institute for Genomic Research in Rockville, Maryland. "We don't know how long this infusion of money is going to last, and I have yet to find anyone who is willing to make any guesses about how long that might be."

Some infectious-disease researchers, however, say that the new emphasis on biodefence has already caused a cultural shift in their discipline. Olaf Schneewind, who heads the NIAID-funded regional biodefence centre at the University of Chicago, argues that centres such as his have changed microbiology by bringing the ethos of 'big science' to the field. "The research groups have become larger, and the new centres involve a lot of different talents and efforts," he says.

Erika Check is Nature's Washington biomedical correspondent.

1. Nature 421, 771 (2003).

2. Rosengard, A. M., Liu, Y., Nie, Z. \& Jimenez, R. Proc. Natl Acad. Sci. USA 99, 8808-8813 (2002).

Lachmann, P. J. Proc. Natl Acad. Sci. USA 99, 8461-8462 (2002). 